\title{
ОРГАНІЗАЦІЯ ФАРМАЦЕВТИЧНОЇ ДОПОМОГИ В УКРАЇНІ: РЕАЛІЇ АПТЕЧНОГО ВИГОТОВЛЕННЯ ЛІКАРСЬКИХ ЗАСОБІВ
}

\author{
() О. С. Самборський ${ }^{1}$, О. М. Євтушенко를 М. М. Слободянюк \\ ДВНЗ «Івано-Франківський національний медичний університет» ${ }^{1}$ \\ Національний фрармацевтичний університет², Харків \\ aptekar05@ukr.net
}

\begin{abstract}
Мета роботи. Аналіз стану екстемпорального виготовлення лікарських засобів в Україні та вивчення можливих шляхів подальшого розвитку цього виду фрармацевтичної допомоги.

Матеріали і методи. У роботі використано загальнонаукові та спеціальні методи: системного аналізу, історичний, аналітичний, маркетингових досліджень, кластерний аналіз. Інформаційну базу досліджень становили статистичні матеріали МО3 України та інших організацій, сайти вітчизняних та закордонних аптек, публікації.

Результати й обговорення. Проаналізовано асортимент виробничих аптек різних регіонів України. Отримані дані свідчать, що найбільш поширеними є групи екстемпоральних лікарських засобів, які застосовують в алергології, дерматології, педіатрії, стоматології, остальмології, проктології, неврології, для лікування грипутаГРВІ, анальгетики для місцевого застосування, засоби для електрофорезу. Проведено аналіз регіонів України щодо забезпеченості виробничими аптеками, який свідчить про суттєве скорочення останніх - частка виробничих аптек за областями не перевищує 3,8 \% від загальної кількості аптек. Слід зазначити, що за певними територіями виробничу практику в аптеках зведено до мінімуму - у Вінницькій, Донецькій, Кіровоградській, Луганській, Полтавській та Закарпатській областях кількість виробничих аптек не перевищує 1\%. Також проведено кластерний аналіз, що розподілив регіони України за ступенем забезпеченості виробничими аптеками та показниками захворюваності.

Висновки. Охарактеризовано асортимент екстемпоральної рецептури українських аптек із погляду фрармакологічної спрямованості препаратів, а також форм випуску. Проведено аналіз фрізичної доступності виробничих аптек. Відзначається низька доступність екстемпоральної рецептури в сільській місцевості, де на сьогодні налічується 21 аптека за всіма регіонами, а це становить 5,9 \% від загальної кількості усіх виробничих аптек по Україні. Проведений та опрацьований кластерний аналіз дав змогу показати взаємний вплив рівня забезпеченості аптеками (включно виробничі) та показників захворюваності в регіонах.
\end{abstract}

Ключові слова: фрармація; лікарські засоби; екстемпоральне виготовлення; Україна.

Вступ. Екстемпоральне виготовлення ліків існувало ще за часів Гіппократа і продовжує існувати до сьогодні. Воно має історичний дух і є для людства не тільки історичною пам'яткою, але й засобом фрармацевтичної допомоги. Виготовлення в умовах аптеки на сьогодні є досить важливою темою. Ії̈ можна розглядати з боку перспективи розвитку фрармацевтичної галузі та з погляду ефективного фрункціонування аптеки та можливих прибутків [1-4].

У зв'язку з вищенаведеним, метою дослідження став аналіз стану екстемпорального виготовлення лікарських засобів (далі - Л3) в Україні та вивчення можливих шляхів подальшого розвитку цього виду фрармацевтичної допомоги.

Матеріали і методи. У роботі використано загальнонаукові та спеціальні методи: системного аналізу, історичний, аналітичний, маркетингових досліджень, кластерний аналіз. Інформаційну базу досліджень становили статистичні матеріали МОЗ України та ін- ших організацій, сайти вітчизняних та закордонних аптек, публікації.

Результати й обговорення. На сьогодні, майже усі аптеки США, Великої Британії, Чехії, Нідерландів, Швеції, Німеччини, Угорщини та Польщі виготовляють ЛЗ в умовах аптеки. Ці аптеки не є значними конкурентами для промислового виробництва, адже виготовляють ті ліки, які не може виготовити промисловість, та беруть на себе особливі функції, наприклад, в умовах стаціонарів. На сьогодні перевагами екстемпорального виготовлення є: точне дозування відповідно до віку та маси хворого, відсутність консервантів, стабілізаторів та барвників, відсутність можливості фральсифрікації, доступність цін; можливість виготовлення Л3, яким немає аналогів (немає адекватної лікарської форми, дитячого дозування або дозування для літніх) [1-3].

Поряд із перевагами в екстемпорального виготовлення є недоліки: 
Організація роботи аптечних підприємств

Organization of pharmaceutical structures' work

- низькооплачувана ручна праця в Україні;

- $\quad$ короткий термін придатності екстемпоральних ліків;

- можлива фрізична та хімічна несумісність;

- можлива мікробна контамінація;

- потреба у великому асортименті субстанцій при невеликій їх кількості.

Виготовлення ліків в аптеках існує вже досить давно, перші згадки про такі ліки були у 1193-1184 рр. до н. е., за часів Гіппократа. 31880 до 1903 р. кількість аптек по всій Україні поступово збільшувалась (рис. 1) [1-3].

У 20-х роках минулого століття лЗ аптечного виробництва займали 80 \% від усіх ЛЗ, які на той час реалізовувалися, а вже в кінці 80-х років частка екстемпорального виготовлення знизилася на 13,5 \%. В 90-х роках відбулися кардинальні зміни в аптечному виготовлені, викликані переходом країни до ринкових відносин - питома вага екстемпоральних ЛЗ знизилася до 5-7 \%. На початку нового століття почалось масове закриття рецептурно-виробничих відділів, в результаті чого міське та сільське населення залишилося без певного виду фрармацевтичної допомоги. Встановлено, що на сьогодні кількість аптек, що займається власним виготовленням ліків, не перевищує 2 \% (рис. 2).

Так, наприклад, якщо у Харківській області в 1995 р. нараховували 185 аптек, то в 2000 р. - 88 аптек, а згодом через 7 років (у 2007 р.) їх кількість зменшилась більш ніж на 20 - залишилося всього 65, у 2016 - таких аптек тільки 28 (рис. 3) [4, 5].

Проаналізовано асортимент у 10 виробничих аптеках різних регіонів України, зокрема в містах Харків, Івано-Франківськ, Київ та Славута. Отримані дані

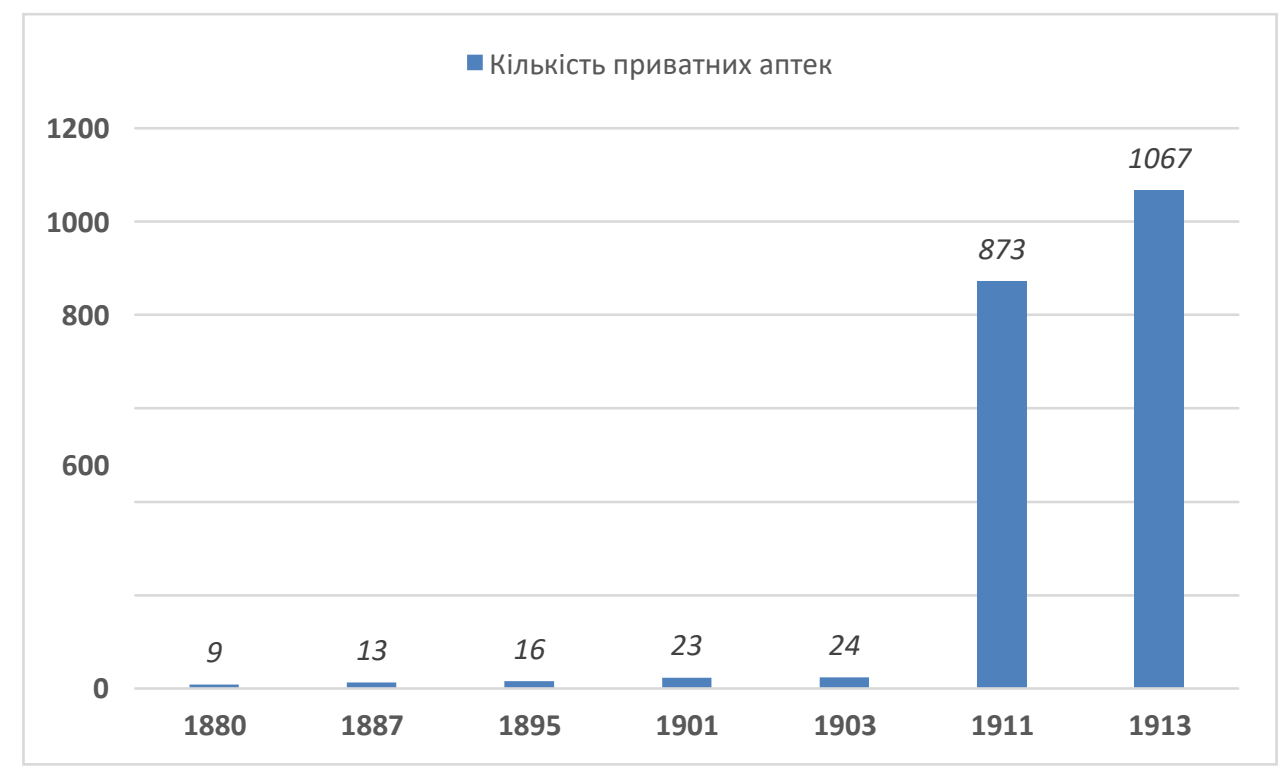

Рис. 1. Кількість аптек у 1880-1913 рр. в Україні.

в Відсоток загальної кількості аптек

- Відсоток виробничих аптек

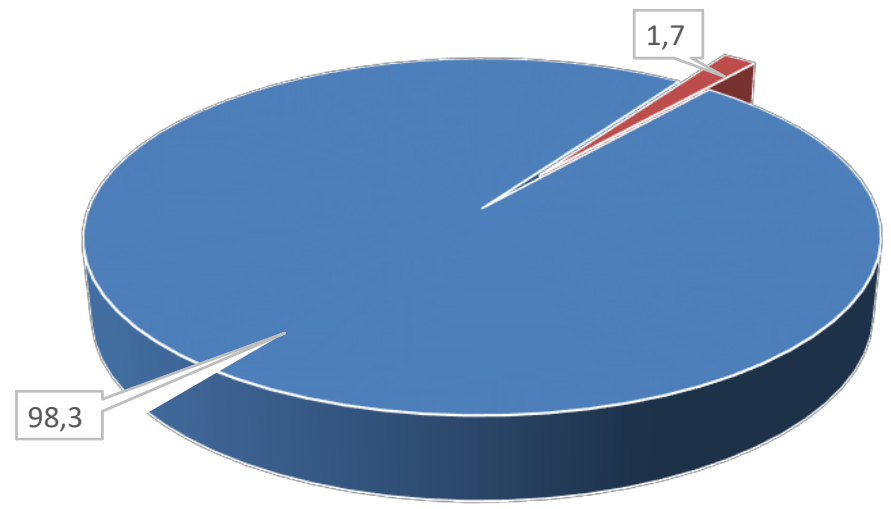

Рис. 2. Частка виробничих аптек серед загальної кількості аптек в Україні.

ISSN 2312-0967. Фармацевтичний часопис. 2017. № 4 
Організація роботи аптечних підприємств Organization of pharmaceutical structures' work

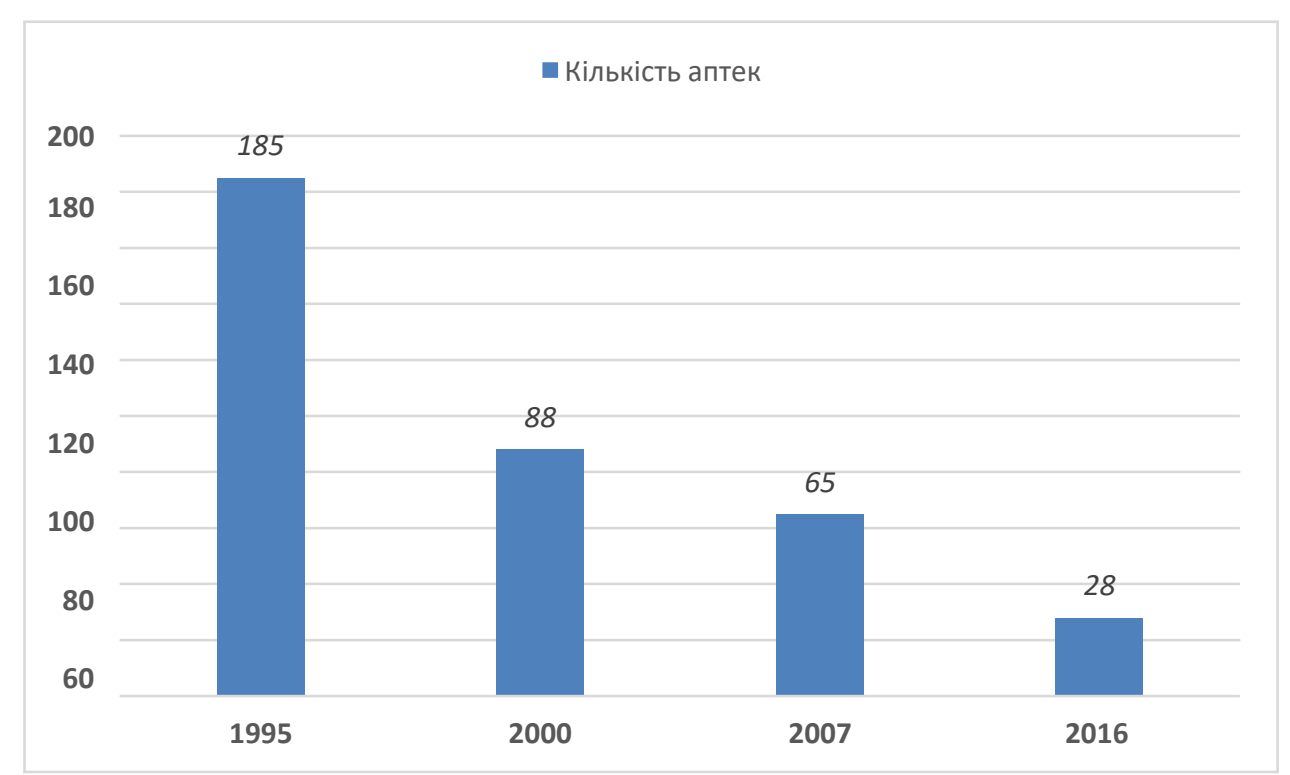

Рис. 3. Кількість виробничих аптек у Харківській області у 1995-2016 рр.

свідчать, що найбільш поширеними є групи екстемпоральних Лз для застосування в: алергології, дерматології, педіатрії, стоматології, офтальмології, проктології, неврології, для лікування грипу та ГРВІ, анальгетики для місцевого застосування, засоби для електрофорезу. Користуються попитом та найчастіше виготовляються українськими аптеками такі лікарські форми (рис. 4).
Наступним кроком стало дослідження ситуації в кожному регіоні України за допомогою Реєстру місць провадження діяльності 3 оптової та роздрібної торгівлі ЛЗ, даних Державної служби статистики та Центру медичної статистики МОЗ України [6-8]. Результати аналізу щодо забезпечення виробничими аптеками у 2016 р. наведено в таблицях 1-4.

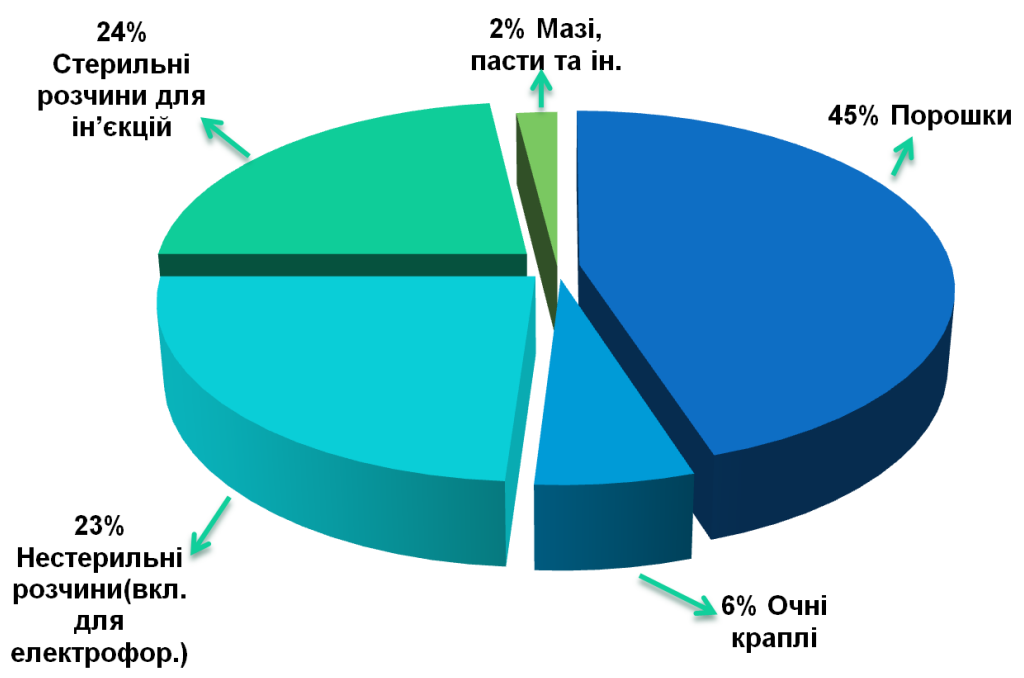

Рис. 4. Найпоширеніші лікарські фрорми для екстемпорального виготовлення в аптеках України.

Таблиця 1. Аналіз кількості аптек із виробничими відділами за всіма областями України

\begin{tabular}{|l|c|c|c|}
\hline \multicolumn{1}{|c|}{ Область } & $\begin{array}{c}\text { Загальна } \\
\text { к-сть аптек }\end{array}$ & $\begin{array}{c}\text { К-сть } \\
\text { виробничих аптек }\end{array}$ & $\begin{array}{c}\text { Частка аптек 3 ліцензією на } \\
\text { виготовлення, \% }\end{array}$ \\
\hline 1 & 2 & 3 & 4 \\
\hline Вінницька & 888 & 3 & 0,34 \\
\hline Волинська & 484 & 7 & 1,45 \\
\hline Дніпропетровська & 1760 & 18 & 1,02 \\
\hline
\end{tabular}

ISSN 2312-0967. Pharmaceutical review. 2017. № 4 
Організація роботи аптечних підприємств

Organization of pharmaceutical structures' work

Продовження табл. 1

\begin{tabular}{|c|c|c|c|}
\hline 1 & 2 & 3 & 4 \\
\hline Донецька & 1715 & 17 & 0,99 \\
\hline Житомирська & 662 & 12 & 1,81 \\
\hline Закарпатська & 772 & 5 & 0,65 \\
\hline Запорізька & 910 & 14 & 1,54 \\
\hline Івано-Франківська & 839 & 15 & 1,79 \\
\hline Київська & 1077 & 16 & 1,49 \\
\hline Кіровоградська & 586 & 2 & 0,34 \\
\hline Луганська & 839 & 5 & 0,60 \\
\hline Львівська & 1303 & 44 & 3,38 \\
\hline м. Київ & 1707 & 60 & 3,51 \\
\hline Миколаївська & 598 & 7 & 1,17 \\
\hline Одеська & 1452 & 18 & 1,24 \\
\hline Полтавська & 784 & 4 & 0,51 \\
\hline Рівненська & 580 & 15 & 2,59 \\
\hline Сумська & 612 & 7 & 1,14 \\
\hline Тернопільська & 625 & 10 & 1,60 \\
\hline Харківська & 1451 & 27 & 1,86 \\
\hline Херсонська & 546 & 7 & 1,28 \\
\hline Хмельницька & 841 & 17 & 2,02 \\
\hline Черкаська & 805 & 30 & 3,73 \\
\hline Чернівецька & 524 & 8 & 1,53 \\
\hline Чернігівська & 459 & 10 & 2,18 \\
\hline Всього & 22819 & 378 & 1,66 \\
\hline
\end{tabular}

Таблиця 2. Характеристика кількості аптек із виробничими відділами на 1000 чол. населення України

\begin{tabular}{|l|c|c|c|c|}
\hline \multicolumn{1}{|c|}{ Область } & $\begin{array}{c}\text { Загальна } \\
\text { к-сть виробничих } \\
\text { аптек }\end{array}$ & $\begin{array}{c}\text { Середньорічна } \\
\text { чисельність населення, } \\
\text { обидві статі 2015 р. }\end{array}$ & $\begin{array}{c}\text { К-сть аптек } \\
\text { на 1000 } \\
\text { чол. }\end{array}$ & $\begin{array}{c}\text { Частка виробничих } \\
\text { аптек на 1000 чол., } \\
\%\end{array}$ \\
\hline Вінницька & 2 & 3 & 4 & 5 \\
\hline Волинська & 3 & 1603488 & 0,00187 & 0,82 \\
\hline Дніпропетровська & 7 & 1040190 & 0,00673 & 2,94 \\
\hline Донецька & 18 & 3273328 & 0,00550 & 2,40 \\
\hline Житомирська & 17 & 1965436 & 0,00865 & 3,78 \\
\hline Закарпатська & 12 & 1256735 & 0,00955 & 4,17 \\
\hline Запорізька & 5 & 1256737 & 0,00398 & 1,74 \\
\hline Івано-Франківська & 14 & 1765137 & 0,00793 & 3,47 \\
\hline Київська & 15 & 1379827 & 0,01087 & 4,75 \\
\hline Кіровоградська & 16 & 1723455 & 0,00928 & 4,06 \\
\hline Луганська & 2 & 974164 & 0,00205 & 0,90 \\
\hline Львівська & 5 & 719417 & 0,00695 & 3,04 \\
\hline м. Київ & 44 & 2519429 & 0,01746 & 7,63 \\
\hline Миколаївська & 60 & 2846667 & 0,02108 & 9,21 \\
\hline Одеська & 7 & 1163627 & 0,00602 & 2,63 \\
\hline
\end{tabular}

ISSN 2312-0967. Фармацевтичний часопис. 2017. № 4 
Організація роботи аптечних підприємств Organization of pharmaceutical structures' work

Продовження табл. 2

\begin{tabular}{|l|c|c|c|c|}
\hline \multicolumn{1}{|c|}{1} & 2 & 3 & 4 & 5 \\
\hline Полтавська & 4 & 1441137 & 0,00278 & 1,21 \\
\hline Рівненська & 15 & 1160091 & 0,01293 & 5,65 \\
\hline Сумська & 7 & 1121256 & 0,00624 & 2,73 \\
\hline Тернопільська & 10 & 1066685 & 0,00937 & 4,10 \\
\hline Харківська & 27 & 2715666 & 0,00994 & 4,35 \\
\hline Херсонська & 7 & 1066444 & 0,00656 & 2,87 \\
\hline Хмельницька & 17 & 1298079 & 0,01310 & 5,72 \\
\hline Черкаська & 30 & 1248187 & 0,02403 & 10,50 \\
\hline Чернівецька & 8 & 906900 & 0,00882 & 3,86 \\
\hline Чернігівська & 10 & 1047131 & 0,00955 & 4,17 \\
\hline Всього & 378 & 38944595 & 0,22880 & 100 \\
\hline
\end{tabular}

Таблиця 3. Територіальна доступність аптек із виробничими відділами на 1000 чол. міського населення України

\begin{tabular}{|c|c|c|c|c|}
\hline Область & $\begin{array}{c}\text { Загальна к-сть } \\
\text { виробничих } \\
\text { аптек }\end{array}$ & $\begin{array}{c}\text { Середньорічна } \\
\text { чисельність міського } \\
\text { населення, обідві статі } \\
2015 \text { р. }\end{array}$ & $\begin{array}{c}\text { К-сть аптек } \\
\text { на } 1000 \text { чол. } \\
\text { міського } \\
\text { населення }\end{array}$ & $\begin{array}{c}\text { Частка виробничих } \\
\text { аптек на } 1000 \text { чол. } \\
\text { міського населення, } \\
\%\end{array}$ \\
\hline Вінницька & 3 & 805752 & 0,00372 & 1,1 \\
\hline Волинська & 7 & 539423 & 0,01298 & 3,7 \\
\hline Дніпропетровська & 18 & 2733980 & 0,00658 & 1,9 \\
\hline Донецька & 17 & 1659408 & 0,01024 & 2,9 \\
\hline Житомирська & 9 & 735516 & 0,01224 & 3,5 \\
\hline Закарпатська & 5 & 462128 & 0,01082 & 3,1 \\
\hline Запорізька & 14 & 1358300 & 0,01031 & 2,9 \\
\hline Івано-Франківська & 13 & 596364 & 0,02180 & 6,2 \\
\hline Київська & 13 & 1064149 & 0,01222 & 3,5 \\
\hline Кіровоградська & 2 & 609006 & 0,00328 & 0,9 \\
\hline Луганська & 5 & 514736 & 0,00971 & 2,8 \\
\hline Львівська & 44 & 1524050 & 0,02887 & 8,2 \\
\hline м. Київ & 60 & 2846667 & 0,02108 & 6,0 \\
\hline Миколаївська & 7 & 789959 & 0,00886 & 2,5 \\
\hline Одеська & 18 & 1584845 & 0,01136 & 3,2 \\
\hline Полтавська & 4 & 883974 & 0,00453 & 1,3 \\
\hline Рівненська & 14 & 548892 & 0,02551 & 7,3 \\
\hline Сумська & 7 & 763935 & 0,00916 & 2,6 \\
\hline Тернопільська & 9 & 471112 & 0,01910 & 5,4 \\
\hline Харківська & 25 & 2180947 & 0,01146 & 3,3 \\
\hline Херсонська & 7 & 650257 & 0,01076 & 3,1 \\
\hline Хмельницька & 15 & 724659 & 0,02070 & 5,9 \\
\hline Черкаська & 27 & 704455 & 0,03833 & 10,9 \\
\hline Чернівецька & 6 & 385276 & 0,01557 & 4,4 \\
\hline Чернігівська & 8 & 668607 & 0,01197 & 3,4 \\
\hline Всього & 357 & 25806397 & 0,35116 & 100 \\
\hline
\end{tabular}

ISSN 2312-0967. Pharmaceutical review. 2017. № 4 
Організація роботи аптечних підприємств

Organization of pharmaceutical structures' work

Таблиця 4. Територіальна доступність аптек із виробничими відділами на 1000 чол. сільського населення України

\begin{tabular}{|c|c|c|c|c|}
\hline Область & $\begin{array}{l}\text { К-сть аптек } \\
\text { у сільській } \\
\text { місцевості }\end{array}$ & $\begin{array}{c}\text { Середньорічна чисельність } \\
\text { сільського населення, } \\
\text { обидві статі } 2015 \text { р. }\end{array}$ & $\begin{array}{c}\text { К-сть аптек } \\
\text { на } 1000 \text { чол. } \\
\text { сільського } \\
\text { населення }\end{array}$ & $\begin{array}{c}\text { Частка аптек } \\
\text { на } 1000 \text { чол. } \\
\text { сільського } \\
\text { населення, \% }\end{array}$ \\
\hline Вінницька & - & 797736 & - & - \\
\hline Волинська & - & 500767 & - & - \\
\hline Дніпропетровська & - & 539348 & - & - \\
\hline Донецька & - & 306028 & - & - \\
\hline Житомирська & 3 & 521219 & 0,00576 & 15,1 \\
\hline Закарпатська & - & 794609 & - & - \\
\hline Запорізька & - & 406837 & - & - \\
\hline Івано-Франківська & 2 & 783463 & 0,00255 & 6,7 \\
\hline Київська & 3 & 659306 & 0,00455 & 12,0 \\
\hline Кіровоградська & - & 365158 & - & - \\
\hline Луганська & - & 204681 & - & - \\
\hline Львівська & - & 995379 & - & - \\
\hline м. Київ & - & - & - & - \\
\hline Миколаївська & - & 373668 & - & - \\
\hline Одеська & - & 800537 & - & - \\
\hline Полтавська & - & 557163 & - & - \\
\hline Рівненська & 1 & 611199 & 0,00164 & 4,3 \\
\hline Сумська & - & 357321 & - & - \\
\hline Тернопільська & 1 & 595573 & 0,00168 & 4,4 \\
\hline Харківська & 2 & 534719 & 0,00374 & 9,8 \\
\hline Херсонська & - & 416187 & - & - \\
\hline Хмельницька & 2 & 573420 & 0,00349 & 9,2 \\
\hline Черкаська & 3 & 543732 & 0,00552 & 14,5 \\
\hline Чернівецька & 2 & 521624 & 0,00383 & 10,1 \\
\hline Чернігівська & 2 & 378524 & 0,00528 & 13,9 \\
\hline Всього & 21 & 13138198 & 0,03804 & 100,0 \\
\hline
\end{tabular}

Аналіз свідчить про низький рівень забезпечення виробничими аптеками - частка виробничих аптек за областями не перевищує 3,8 \% від загальної кількості аптек. Слід зазначити, що за певними територіями виробничу практику в аптеках майже повністю «знищено» - у Вінницькій, Донецькій, Кіровоградській, Луганській, Полтавській та Закарпатській областях кількість виробничих аптек не перевищує 1\%. Досліджено частку виробничих аптек відносно кількості міського та сільського населення (табл. 2-4).

За отриманими даними на сьогодні забезпечення міського населення екстемпоральними ліками набагато вище, ніж сільського. Найвища територіальна доступність простежується у м. Київ, у містах Івано-Франківської, Черкаської, Рівненської, Львівської областей. Однак у регіонах ситуація досить складна. На сьогодні в сільській місцевості налічується лише 21 виробнича аптека, а це становить 5,9 \% від загальної кількості усіх виробничих аптек. 3 огляду на те, що в нашій країні 3 перехідною економікою спостерігається зменшення споживчої спроможності громадян, ліки, виготовлені ех tempore, потенційно користуються великим попитом, особливо в віддалених регіонах, де проживають декретовані верстви населення - люди похилого віку, інваліди, діти, вагітні, але доступ до такого виду фармацевтичної допомоги вкрай обмежений.

У зв'язку з вищезазначеним, було проведено кластерний аналіз та проаналізовано його результати, який дав змогу охарактеризувати стан фрармацевтичного ринку України за ступенем забезпечення виробничими аптеками та взаємозв'язку цих показників із захворюваністю в регіонах. Для нашого дослідження було обрано агломеративний метод Уорда. На прикладі алгоритму видно, як при кожному кроці об'єкти групуються за схожими характеристиками, утворюючи кластери.

Для проведення аналізу було використано п'ять характеристик, серед яких: загальна чисельність ап-

ISSN 2312-0967. Фармацевтичний часопис. 2017. № 4 
тек, кількість виробничих аптек; середньорічна чисельність населення, поширення хвороб на 100000 чол., захворюваність на хвороби, які входять в календар профілактичних щеплень України на 100000 чол. [6-8]. Дані щодо загальної кількості аптек включають кількість усіх аптек (в т. ч. виробничих), зареєстрованих в Україні. Під цим розуміють кількість аптек, які мають актуальну ліцензію на виготовлення ліків станом на березень 2017 року. Середньорічна чисельність населення розрахована як середнє арифметичне з чисельності на початок і кінець календарного року (обидві статі). Поширення хвороб на 100000 чол. включає всі випадки захворювань (як вперше зареєстрованих, так і виявлених в поточному році) на 100000 чол. населення. Захворюваність на хвороби, які входять в календар профілактичних щеплень України на 100000 чол., включає всі випадки вперше зареєстрованих хворих на хвороби, які входять в календар профрілактичних щеплень України. За всіма характеристиками, крім кількості аптек, дані були доступні за 2015 рік - в рамках цієї роботи різницю вважають маргінальною та не впливає на результат.

Існує дві розповсюджені групи методів кластерного аналізу: ієрархічні та неієрархічні. Оскільки кластерний аналіз буде проводитися з огляду на обмежену кількість об'єктів, а точніше 24 області та м. Київ, апріорі ми не можемо зробити висновок про кількість кластерів, тому був обраний ієрархічний метод Уорда. Для проведення кластерного аналізу нами використано статистичну програму «IBM SPSS Statistics (Version 23)», вбудований фуннціонал якої дозволяє провести кластерний аналіз за допомогою зазначеного методу [9]. На першому кроці 25 об'єктів (24 області та м. Київ) і 5 змінних (характеристики, які перераховані вище), за якими оцінювались об'єкти, були занесені в програму для їх подальшого використання в розрахунках. На другому кроці комп'ютерна статистична програма «IBM SPSS Statistics» застосовує агломеративний (об'єднувальний) алгоритм сортування даних [9] для кластеризації об'єктів. При застосуванні агломеративного методу Уорда на початку аналізу кількість кластерів дорівнює кількості об'єктів, тобто кожен кластер включає лише один об'єкт. У процесі аналізу об'єкти поступово групуються (кластери поєднуються) з огляду на те, наскільки вони схожі за своїми характеристиками.

У ході розрахунків отримано чотири кластери відповідно до рівня забезпечення регіонів аптеками 3 екстемпоральним виготовленням ліків (рис. 5).

3 огляду на результати кластеризації, наведені на рисунку 5, можна визначити фрормування кількох кластерів, варіанти яких наведені нижче:

- Варіант 1

- Рівненська, Тернопільська, Волинська, Житомирська, Хмельницька, Черкаська, Чернівецька, Чернігівська, Вінницька, Івано-Франківська, Київська,
Кіровоградська, Херсонська, Закарпатська, Миколаївська, Полтавська, Сумська, Запорізька, Донецька, Луганська;

- Одеська, Харківська, Дніпропетровська, м. Київ, Львівська.

- Варіант 2

- Рівненська, Тернопільська, Волинська, Житомирська, Хмельницька, Черкаська, Чернівецька, Чернігівська, Вінницька, Івано-Франківська, Київська, Кіровоградська, Херсонська, Закарпатська, Миколаївська, Полтавська, Сумська, Запорізька;

- Донецька, Луганська;

- Одеська, Харківська, Дніпропетровська, м. Київ, Львівська.

\section{- Варіант 3}

- Рівненська, Тернопільська, Волинська, Житомирська, Хмельницька, Черкаська, Чернівецька, Чернігівська, Вінницька, Івано-Франківська, Київська;

- Кіровоградська, Херсонська, Закарпатська, Миколаївська, Полтавська, Сумська, Запорізька;

- Донецька, Луганська;

- Одеська, Харківська, Дніпропетровська, м. Київ, Львівська.

Рішення зупинитися на двох кластерах могло призвести до того, що в кожний кластер могли потрапити об'єкти, які дуже відрізняються за своїми характеристиками. При урахуванні трьох кластерів розмежування стає більш чітким, але на дендрограмі видно, що найбільший із них насправді складається 3 двох частин (з двох кластерів). Оскільки розділення цього кластера чітко видно, авторами було прийнято рішення для аналізу взяти чотири кластери, відділивши дендрограму лінією синього кольору на тому місці, де чітко видно розділення об'єктів на чотири кластери (рис. 5). Для кращого наочного прикладу ці чотири кластери з об'єктами, які в них входять, були зображені різними кольорами на карті України (рис. 6).

Найкращі показники отримав кластер № 2: Одеська, Харківська, Дніпропетровська, Львівська області, м. Київ. Низьку забезпеченість виробничими аптеками та гірші показники захворюваності показав кластер № 1, куди увійшли західні та деякі центральні області України (11 областей) - Рівненська, Тернопільська, Волинська, Житомирська, Хмельницька, Черкаська, Чернівецька, Чернігівська, Вінницька, ІваноФранківська, Київська області. Далі йде кластер № 4 - центральні та південні області України: Кіровоградська, Херсонська, Закарпатська, Миколаївська, Полтавська, Сумська, Запорізька. I найгірші показники (кластер № 3) отримали східні регіони України - Донецька і Луганська області, що зумовлено ситуацією на даній території, яка потребує коректуючих заходів щодо поліпшення рівня фрармацевтичної допомоги. Тим більше, що в умовах нестабільності, викликаної військовими діями, аптеки з виготовленням ліків можуть оперативно реагувати на потреби військової та

ISSN 2312-0967. Pharmaceutical review. 2017. № 4 


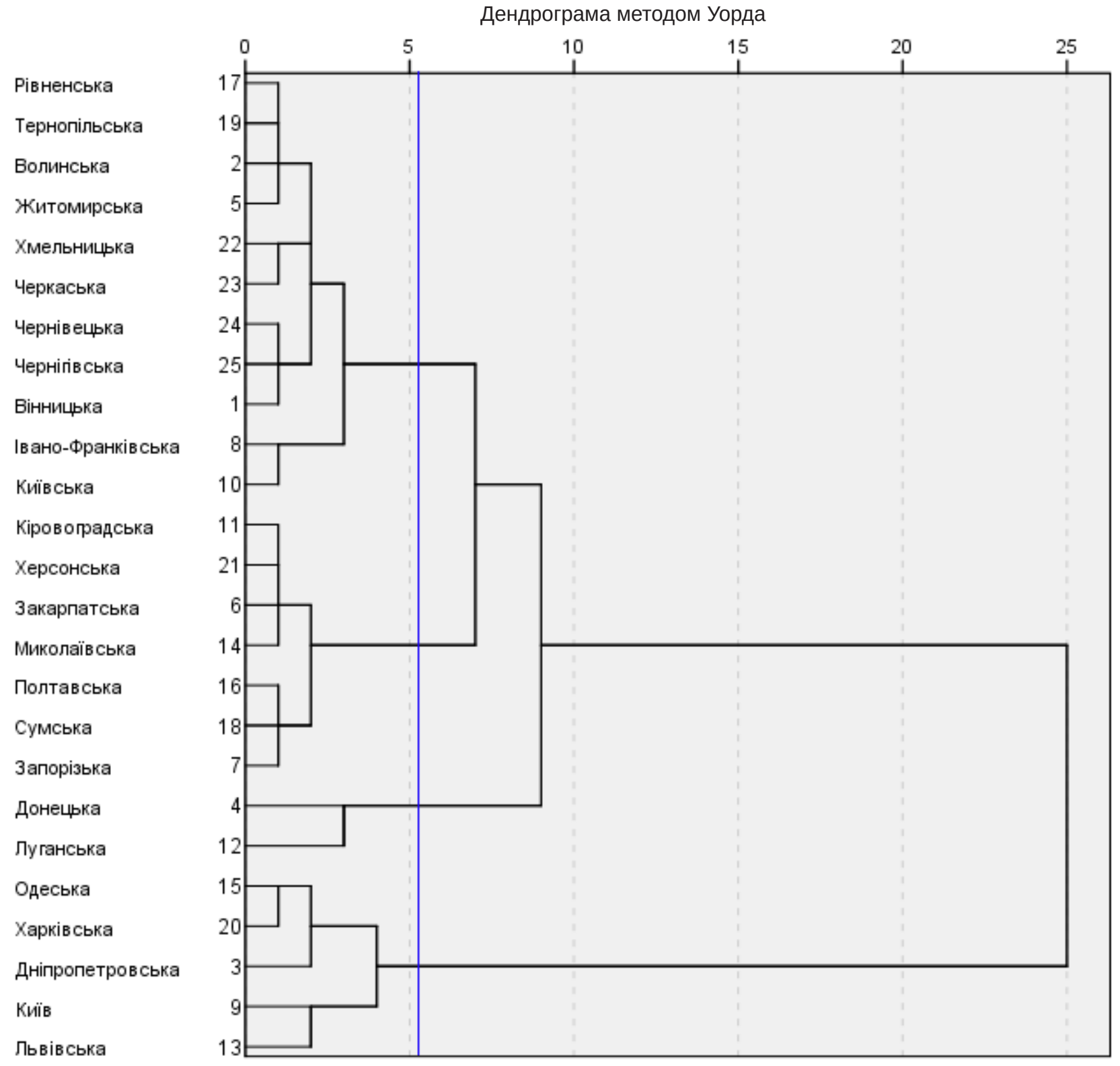

Рис. 5. Дендрограма, отримана в ході проведення кластерного аналізу.

цивільної медицини в необхідних Л3, наприклад, стерильних розчинах.

Дослідження аптек із можливістю екстемпорального виготовлення проводили не тільки в Україні, але і в інших країнах для визначення можливості використання світового досвіду саме для українських аптек. Так, зокрема, було досліджено асортимент екстемпоральних ЛЗ в Естонії, Латвії, а також в аптечних мережах Королівства Швеція [10-13]. Слід зазначити, що у всіх наведених країнах існує екстемпоральна рецептура, але найбільш прогресивною виявилася шведська фрармація - на сьогодні екстемпоральна рецептура займає 1/5 від всіх лікарських призначень [14]. В шведських аптеках виробляють або дозують (наприклад, в інфузомати) ЛЗ наступних фрармаколо- гічних груп: глюкокортикоїди для місцевого застосування, антибіотики, препарати для лікування псоріазу, дерматопротектори, протигрибкові, гіполіпідемічні препарати, блокатори кальцієвих каналів, бета-адреноблокатори, діуретики, гематологічні препарати, електроліти, розчини для парентерального харчування, антианемічні, гемостатики, протипухлинні препарати (рис. 7). Аптеки Швеції також виробляють нехарактерну для вітчизняних аптек форму лікарських препаратів - шприци (з антибіотиками, анальгетиками, анестетиками) (рис. 8). Шведські лікарі та фрармацевти зазначають, що така практика дозволяє виключити помилку медичного персоналу, дозволяє заощадити час (в середньому 20 хвилин на одного стаціонарного хворого) та кошти (в середньому при-

ISSN 2312-0967. Фармацевтичний часопис. 2017. № 4 
Організація роботи аптечних підприємств Organization of pharmaceutical structures' work

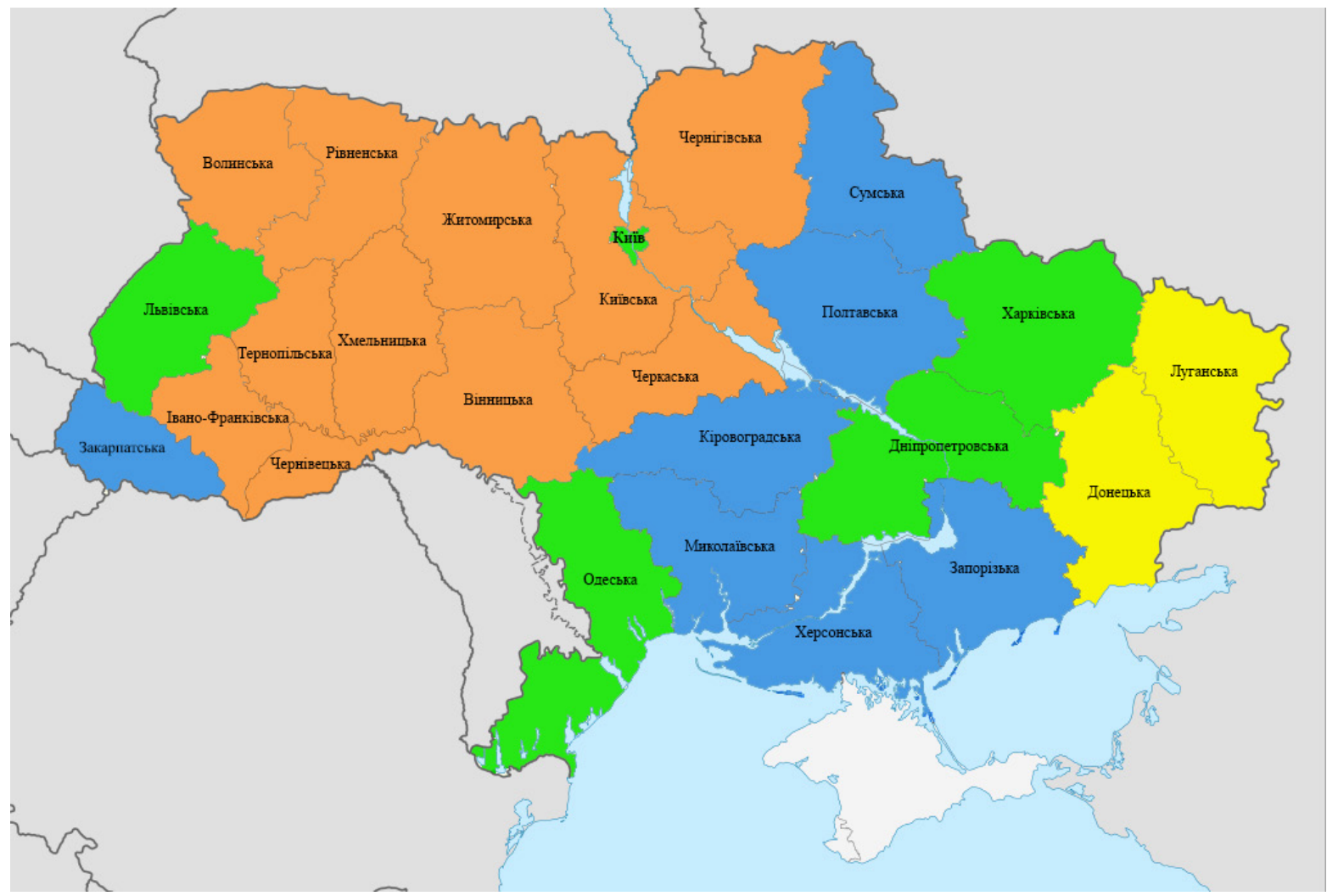

Рис. 6. Регіони України, згруповані у кластери.

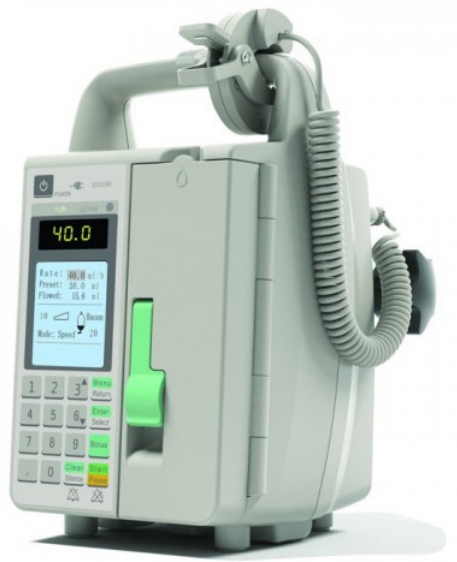

Рис. 7. Інсрузійний дозатор з модулем автоматичного розрахунку.

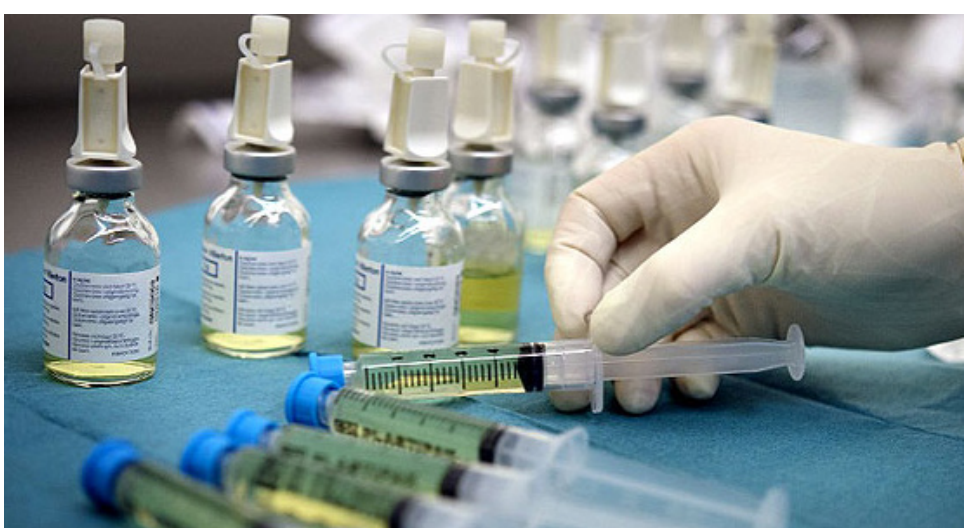

Рис. 8. Шприци, що заповнюються в асептичному відділі аптеки. близно 6 євро на кожному заповненому шприці), гарантувати безпеку пацієнтів, забезпечити стандарти якості (вимоги до приміщення та професійного рівня фрармацевтів), створити безпечні умови для медичного персоналу та хворих, схильних до алергічних станів. Також має широке застосування електронна система виписування рецептів та замовлення рецептів через сайт аптеки або через мобільний додаток. Забирають замовлення в найближчій аптеці або отримують за допомогою експрес-доставки, заплатити можна через сайт або в аптеці через спеціальний лічильник для попередньо замовлених препаратів.
Завдяки цій системі люди з обмеженими можливостями, а також тяжко хворі не відчувають труднощів в отриманні екстемпоральних ЛЗ.

Таким чином, закордонний досвід свідчить, що екстемпоральна рецептура має повноцінне життя в інших країнах, користується попитом та виконує певні фрункції, які недоступні іншим категоріям фрармацевтичних товарів. Подальші дослідження можуть бути спрямовані на вивчення можливостей використання закордонного досвіду на території нашої країни, особливо в віддалених регіонах, а також фрінансових та правових аспектів виготовлення екстемпоральних ліків.

ISSN 2312-0967. Pharmaceutical review. 2017. № 4 
Організація роботи аптечних підприємств

Organization of pharmaceutical structures' work

Висновки. 1. Охарактеризовано асортимент екстемпоральної рецептури українських аптек із погляду фрармакологічної спрямованості препаратів, а також фрорм випуску.

2. Проведено аналіз фрізичної доступності виробничих аптек. Спостерігається низька доступність екстемпоральної рецептури в сільській місцевості, де на сьогодні налічується 21 аптека за всіма регіонами, а це становить 5,9\% від загальної кількості усіх виробничих аптек по Україні.

3. Проведений та опрацьований кластерний аналіз, який дав змогу показати взаємний вплив рівня забезпеченості аптеками (включно виробничі) та по- казників захворюваності в регіонах. Найкращу забезпеченість та низький рівень захворюваності показали Одеська, Харківська, Дніпропетровська, Львівська області, м. Київ. Найгірші показники отримали східні регіони України - Донецька і Луганська області, що зумовлено ситуацією на даній території та потребує коректуючих заходів щодо поліпшення рівня фрармацевтичної допомоги.

4. Подальші дослідження можуть бути спрямовані на вивчення можливостей використання закордонного досвіду на території нашої країни, особливо у віддалених регіонах, а також фрінансових та правових аспектів виготовлення екстемпоральних ліків.

\title{
ОРГАНИЗАЦИЯ ФАРМАЦЕВТИЧЕСКОЙ ПОМОЩИ В УКРАИНЕ: РЕАЛИИ АПТЕЧНОГО ИЗГОТОВЛЕНИЯ ЛЕКАРСТВЕННЫХ СРЕДСТВ
}

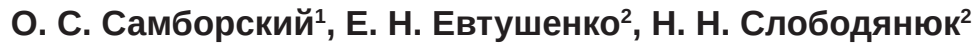 \\ Ивано-Франковский национальный медицинский университет ${ }^{1}$ \\ Национальный фрармацевтический университет², Харьков \\ aptekar05@ukr.net
}

Цель работы. Анализ состояния экстемпорального изготовления лекарственных средств в Украине и изучение возможных путей дальнейшего развития этого вида фрармацевтической помощи.

Материалы и методы. В работе использованы общенаучные и специальные методы: системного анализа, исторический, аналитический, маркетинговых исследований, кластерный анализ. Информационную базу исследований составили статистические материалы МЗ Украины и других организаций, сайты отечественных и зарубежных аптек, публикации.

Результаты и обсуждение. Проанализированы ассортимент производственныхаптекразличных регионов Украины. Полученные данные свидетельствуют, что наиболее распространенными являются группы экстемпоральных лекарственных средств для применения в: аллергологии, дерматологии, педиатрии, стоматологии, офтальмологии, проктологии, неврологии, для лечения гриппа и ОРВИ, анальгетики для местного применения, средства для электрофореза. Проведен анализ регионов Украины по обеспеченности производственными аптеками, который свидетельствует об их существенном сокращении - доля производственных аптек по областям не превышает 3,8 \% от общего количества аптек. Следует отметить, что в некоторых местах производственная практика в аптеках полностью почти сведена к минимуму - в Винницкой, Донецкой, Кировоградской, Луганской, Полтавской и Закарпатской областях количество производственных аптек не превышает 1\%. Одним из этапов исследования стал кластерный анализ, который позволил распределить регионы Украины по степени обеспеченности производственными аптеками и показателями заболеваемости.

Выводы. Охарактеризирован ассортимент экстемпоральной рецептуры украинских аптек с точки зрения фармакологической направленности препаратов, а также форм выпуска. Проведен анализ территориальной доступности производственных аптек. Отмечается низкая доступность экстемпоральной рецептуры в сельской местности, где сегодня насчитывается 21 аптека, а это составляет 5,9 \% от общего количества всех производственных аптек по Украине. Проведена кластеризация регионов, позволившая показать взаимное влияние уровня обеспеченности аптеками (включая производственные) и показателей заболеваемости.

Ключевые слова: фрармация; лекарственные средства; экстемпоральное изготовление; Украина.

ISSN 2312-0967. Фармацевтичний часопис. 2017. № 4 


\title{
ORGANIZATION OF PHARMACEUTICAL CARE IN UKRAINE: REALITIES OF EXTEMPORAL MEDICINES PRODUCTION
}

\author{
O. S. Samborskyi ${ }^{1}$, O. M. levtushenko ${ }^{2}$, N. N. Slobodyanyuk ${ }^{2}$ \\ Ivano-Frankivsk National Medical University, Ivano-Frankivsk ${ }^{1}$ \\ National Pharmaceutical University, Kharkiv² \\ aptekar05@ukr.net
}

The aim of the work. The analysis of the extemporal manufacturing of medicines in Ukraine and the study of possible ways of further development of this type of pharmaceutical care. Statistic materials of the Ministry of Health of Ukraine and other organizations, home and foreign pharmacies sites, publications served as an informational basis of investigations.

Materials and Methods. We used general scientific and special methods: system analysis, historical, analytical, marketing research, cluster analysis.

Results and Discussion. The assortment of production pharmacies of various regions of Ukraine has been analyzed. The data obtained indicate that the most common groups for extemporal production are medicines for use in: allergology, dermatology, pediatrics, dentistry, ophthalmology, proctology, neurology, flu and ARVI treatment, electrophoresis, and analgesic ointments. The analysis of the regions of Ukraine on the availability of production pharmacies indicates their significant reduction - the share of production pharmacies in the regions does not exceed $3.8 \%$ of the total number of pharmacies. It should be noted that in some regions the production practice in pharmacies is almost completely reduced to a minimum - the number of production pharmacies does not exceed $1 \%$ in Vinnytsia, Donetsk, Kirovohrad, Luhansk, Poltava and Zakarpattia regions. One of the stages of the research is cluster analysis, which allows distributing the regions of Ukraine according to level of supply with production pharmacies and incidence rates.

Conclusions. The assortment of the extemporal medicines of Ukrainian pharmacies has been characterized from the point of view of pharmacological orientation of medicines as well as the dosage forms. The analysis of territorial density of production pharmacies has been carried out. It has been noted a low availability of extemporal formulations in rural areas, where today there are 21 pharmacies, which makes $5.9 \%$ of the total number of all manufacturing pharmacies in Ukraine. Clustering of the regions has been carried out, which allowed showing the mutual influence of the level of territorial density of pharmacies (including production) and morbidity indicators.

Key words: pharmacy; medicines; extemporal manufacturing; Ukraine.

\section{Список літератури}

1. Екстемпоральне виготовлення ліків: традиції і проблемні аспекти / О. Заліська, Б. Парновський, Н. Бик, І. Худзік // Щотижневик Аптека. - 2014. - № 22 (943). [Електронний ресурс]. - Режим доступу: http://www.apteka.ua/article/293675. 2. Екстемпоральне виготовлення ліків: аналіз, проблеми, необхідність / М. Л. Сятиня, В. П. Попович, О. М. Глущенко, Н. Г. Коновалова // Фармація України. - Т. 2. Актуальні проблеми сучасної технології ліків та екстемпоральної рецептури. - 2015. - С. 402. - [Електронний ресурс]. - Режим до-ступу: http://nuph.edu.ua/wp- content/uploads /2015/04/ farmatsiya_ukrayiny-_tom_1_aktual-ni-problemy- suchasnoyitehnologiyi-likiv-ta-ekstemporal-noyi-retseptury-.pdf.

3. Практикум з аптечної технології ліків : навч. посіб. для студ. вищ. навч. закладів / О. І. Тихонов, С. О. Тихонова, О. П. Гудзенко та ін.; за ред. О. І. Тихонова, С. О. Тихонової. - Х. : Оригінал, 2014. - 448 с.

4. Alfred-Ugbenbo D. S. Аналіз рецептури екстемпоральних лікарських за-собів в госпітальних аптеках Південної Нігерії. / O. A. Zdoryk, V. A. Georgi-yants // Управління, економіка та забезпечення якості фармації. - 2016. - № 3(47). - С. 46 - 52. - [Електронний ресурс]. - Режим доступу до журн.: uekj.nuph.edu.ua/issue/view/5352.

5. Аптечное производство: есть ли в Украине перспективы для его развития? // Щотижневик Аптека. - 2015. - № 4 (975). [Електронний ресурс]. - Ре-жим до- ступу: http://www.apteka.ua/article/321661

6. Реєстр місць провадження діяльності з оптової та роздрібної торгівлі ЛЗ. [Електронний ресурс]. - Режим доступу: http://portal.diklz.gov.ua/PublicSite/ tradelicense/ tradelicenselist.aspx.

7. Сайт Державної служби статистики України [Електронний ресурс]. - Режим доступу: http://www.ukrstat.gov.ua. 8. Сайт Центру медичної статистики МОЗ України. [Електронний ресурс]. - Режим доступу: http://medstat. gov.ua/ukr/main.html.

9. Mooi E. A Concise Guide to Market Research: The Process, Data, and Methods Using IBM SPSS Statistics / E. Mooi, M. Sarstedt. - Springer-Verlag Berlin Heidelberg, 2011. - P. 237-284.

10. Сайт аптеки «Apoteket». - [Електронний ресурс]. Режим доступу: https://www.apoteket.se/.

11. Сайт аптеки «Kronansapotek». - [Електронний ресурс]. - Режим доступу: http://www.kronansapotek.se/.

12. Сайт аптеки «Apteek». - [Електронний ресурc]. - Peжим доступу: https://www.sudameapteek.ee.

13. Сайт аптеки «Apotheka». - [Електронний ресурс]. Режим доступу: https://apotheka.ee/.

14. Головко И. Индивидуальный рецепт // Вісник: осріційно про податки. - [Електронний ресурс]. - Режим доступу: http://www.visnuk.com.ua/ru/pubs/id/8689

ISSN 2312-0967. Pharmaceutical review. 2017. № 4 
Організація роботи аптечних підприємств Organization of pharmaceutical structures' work

\section{References}

1. Zaliska O, Parnovsky B, Byk N, Hudzik I. [Extemporal preparation of drugs: traditions and problem aspects]. Weekly Drugstore 2014;22. Ukrainian. [Electronic resource, Ukrainian]. Available from: http://www.apteka.ua/ article/293675. [Accessed July 2017].

2. Siatynia ML, Popovych VP, Hlushschenko OM, Konovalova $\mathrm{NH}$. [Extemporal preparation of drugs: analysis, problems, necessity]. Pharmacy of Ukraine Volume 2, Actual problems of modern medicine technology and extemporal formulation 2015:402. Ukrainian. [Electronic resource, Ukrainian]. Available from: July http://nuph.edu.ua/wp-content/uploads/2015/04/farmatsiya_ukrayiny-_tom_1_aktualni-problemy-suchasnoyi-tehnologiyi-likiv-ta-ekstemporalnoyi retseptury-.pdf. [Accessed July 2017].

3. Tykhonov OI, Tykhonova SO, Hudzenko OP. [Practice on pharmacy technology: a manual for students in higher education]. Kharkiv, Original 2014:448. Ukrainian.

4. Alfred-Ugbenbo DS, Zdoryk OA, Georgiyants VA. [Analysis of the extemporal drugs formulation in hospital pharmacies in Southern Nigeria]. Management, economics and quality assurance in pharmacy 2016;3:46-52. Ukrainian. [Electronic re-source, Ukrainian]. Available from: http://uekj. nuph.edu.ua/issue/view/5352. [Ac-cessed July 2017]. 5. [Pharmacy production: is there any prospect in Ukraine for its development]. Weekly Drugstore 2015;4. Ukrainian. [Electronic resource, Ukrainian]. Available from: http://www. apteka.ua/article/321661. [Accessed July 2017].

6 . Register of places for conducting wholesale and retail trade of drugs. [Electronic resource, Ukrainian]. Available from: http://portal.diklz.gov.ua/PublicSite/tradelicense/ tradelicenselist.aspx. [Accessed July 2017].

7. Site of the Ukraine State Statistics Service. [Electronic resource, Ukrainian]. Available from: http://www.ukrstat. gov.ua. [Accessed July 2017].

8. Site of the Ukraine Health Ministry Medical Statistics Center. [Electronic resource, Ukrainian]. Available from: http://medstat.gov.ua/ukr/main.html. [Accessed July 2017]. 9. Mooi E, Sarstedt M. A concise guide to market research: the process, data, and methods using IBM SPSS statistics. Springer-Verlag Berlin Heidelberg 2011: 237-284.

10. Drugstore «Apoteket» website. [Electronic resource, Swedish]. Available from: https://www.apoteket.se. [Accessed July 2017].

11. Drugstore «Kronansapotek» website. [Electronic resource, Swedish]. Available from: http://www.kronansapotek.se. [Accessed July 2017].

12. Drugstore «Apteek» website. [Electronic resource, Estonian]. Available from: https://www.sudameapteek.ee. [Accessed July 2017].

13. Drugstore «Apotheka» website. [Electronic resource, Estonian]. Available from: https://apotheka.ee. [Accessed July 2017].

14. Holovko I. [Individual recipe]. Newsletter: officially about taxes. Ukrainian. [Electronic resource, Ukrainian]. Available from: http://www.visnuk.com.ua/ru/pubs/id/8689. [Accessed July 2017]. 